Article

\title{
Study on Properties of Waste Concrete Powder by Thermal Treatment and Application in Mortar
}

\author{
Yuwu Sui ${ }^{1,2, *} \mathbb{D}$, Chuping Ou ${ }^{1}$, Shu Liu ${ }^{1}$, Jinshuai Zhang ${ }^{1}$ and Qingbo Tian ${ }^{1}$ \\ 1 School of Materials Science and Engineering, Shandong Jianzhu University, Jinan 250101, China; \\ ochuping@163.com (C.O.); kz5nd2@163.com (S.L.); zhang59666888@163.com (J.Z.); \\ tqb11@sdjzu.edu.cn (Q.T.) \\ 2 Collaborative Innovation Center of green building of Shandong Province, Jinan 250101, China \\ * Correspondence: herrsui@sdjzu.edu.cn
}

Received: 31 December 2019; Accepted: 27 January 2020; Published: 3 February 2020

\begin{abstract}
Waste concrete must be crushed, screened, and ground in order to produce high-quality recycled aggregate. In this treatment process, $15-30 \%$ waste concrete powder $(<0.125 \mathrm{~mm})$ can be generated. Hydration activity and the reuse of waste concrete powders (WCPs) were studied in this work, and the results illustrated that the particle size changed after a series of thermal treatments at temperatures from $400{ }^{\circ} \mathrm{C}$ to $800{ }^{\circ} \mathrm{C}$. The particle size of waste concrete powder decreased by $700{ }^{\circ} \mathrm{C}$ thermal treatment, and by $600{ }^{\circ} \mathrm{C}$ thermal treatment, it increased. More active elements appeared in WCP heated by $800^{\circ} \mathrm{C}$. Nevertheless, the activity index (AI) of WCP, measured by the ratio of mechanical strengths between mortar with a $30 \%$ replacement of the cement with WCP and normal mortar without WCP, indicated that the WCP by $700{ }^{\circ} \mathrm{C}$ thermal treatment had an optimal AI value, which meant WCP treated at $700{ }^{\circ} \mathrm{C}$ could be used in mortar or concrete as an admixture.
\end{abstract}

Keywords: waste concrete powder; recycled concrete; active materials; particle size; activity index

\section{Introduction}

Due to the large volume of construction and demolition wastes and the deficiency of natural resources, the recycling of building material wastes is urgent and of great importance. The use of building material wastes in concrete can realize up-recycling for building materials.

Concrete wastes can rarely be reused as recycled aggregate to prepare concrete because recycled aggregates "contaminated" with cement paste have lower mechanical properties owing to the presence of cement paste. The workability, mechanical strength, and durability of recycled concrete are adversely affected by recycled aggregate [1-3]. Many experiments were carried out to enhance the quality of recycled aggregate, e.g., incorporation of thermal and mechanical treatment [4] and carbonation treatment to strengthen the recycled aggregates $[5,6]$.

In the process to treat the recycled aggregate, some fine powders including cement paste, sand, and coarse aggregate powder are produced, and some studies focused on the quality improvement and application. Increasing the particle size of recycled cement powder with $450{ }^{\circ} \mathrm{C}$ treatment and partially replacing the cement powder with ground-granulated blast-furnace slag could effectively improve the quality of recycled cement [7]. Xuan and Shui [8,9] reported that new calcium silicate hydrate (C-S-H) was formed and the optimum temperature was at $700-800{ }^{\circ} \mathrm{C}$. Splittgerber and Mueller reported that clinker could be reproduced from cement paste by $1450{ }^{\circ} \mathrm{C}$ thermal treatment [10]. The waste concrete powder (WCP) contained not only cement paste powder but also the fine and coarse aggregate powders; therefore, it had a relatively complicated composition and special properties. It was expected that WCP could be simply used in concrete as an admixture. 
Admixture is a material other than water, aggregates, hydraulic cement, and fiber reinforcement that is used as an ingredient of concrete or mortar and is added to the batch immediately before or during its mixing [11]. In addition, optimal packing can be achieved with some admixtures as finer fillers, concrete absorptivity, and porosity can be reduced, and concrete has a more watertight structure [12]. Admixtures are classified as active mineral admixtures and inert ones [13], where active mineral admixtures are referred to those that contain latent active $\mathrm{SiO}_{2}$ or $\mathrm{Al}_{2} \mathrm{O}_{3}$, e.g., fly ash, slag, and silica fume. Inert mineral admixtures include no latent active compositions, e.g., $\mathrm{CaCO}_{3}$ powder. The use of powders as admixtures in mortar or concrete is judged by standards. On the basis of the stipulation of ASTM C618, cement mortar replaced with $20 \%$ admixture as cement can generate greater than or equal to $75 \%$ of the strength of the reference mortar (without the replacement of cement) at both ages of 7 and 28 days to be regarded as pozzolanic material [14]. Chinese standards have similar requirements for different admixtures; for example, in Chinese standard JG/T 486, the ratio of mechanical strengths at 7 days and 28 days between mortar with $30 \%$ powders replaced with cement and mortar without powders is regarded as an index to judge if a mineral powder can be used as a concrete admixture [13]; another method to determine the pozzolanic activity of an admixture is the Frattini test according to BS EN 196-5:2011 [15,16].

The use of WCP as admixtures in mortar has rarely been investigated. Kim et al. reported that the flow ability and the mechanical strength of mortar used WCP as admixtures decreased, and WCP was certified as a nonreactive powder [17]. Bordy et al. confirmed that cement paste contained $24 \%$ reactive residual anhydrous clinker, and the compressive strengths of mortar with $24 \%$ cement paste replacing cement decreased; however, the compressive strength of mortar with $20 \%$ cement paste replacement could attain $83 \%$ of that of the reference specimen [18]. Zhu et al. reported that WCP containing unhydrated cement particles could be used, in part, to substitute the silica fume or cement as a reactive powder in concrete [19]. Although WCP contained cement paste, unhydrated cement particles in cement paste are related to the water/cement $(\mathrm{w} / \mathrm{c})$ ratio of concrete; the lower the w/c, the most likely the presence of unhydrated cement particles in concrete.

In the process of thermal treatment, chemical reactions, e.g., hydration water release, C-S-H decomposition, and crystal transfer, occurred in concrete; especially, an active material, larnite $\left(\beta-C_{2} S\right)$, was generated at temperatures of $600-900{ }^{\circ} \mathrm{C}$ [20-22], which meant active materials could appear in the heated WCP. The property change of WCP and the use in mortar as an admixture were investigated in this study.

\section{Materials, Methods, and Procedure}

The samples were obtained from the used concrete made before 2015. The cement P.O 42.5 was produced by the Shandong Shanshui cement company. The polycarboxylate plasticizer was produced by the Huadi technology company and could reduce water by $37 \%$. The standard sand was bought from Xiamen AisiO in China.

The used concrete was produced with calcium carbonate as aggregates, and was dealt with by crushing, screening, and grinding. The chemical composition of WCP is shown in Table 1.

Table 1. Chemical ingredients of waste concrete powder (WCP) and cement used in the measure (\%).

\begin{tabular}{ccccccccccc}
\hline & $\mathbf{C a O}$ & $\mathrm{SiO}_{\mathbf{2}}$ & $\mathrm{Al}_{\mathbf{2}} \mathbf{O}_{\mathbf{3}}$ & $\mathrm{Fe}_{\mathbf{2}} \mathbf{O}_{\mathbf{3}}$ & $\mathbf{M g O}$ & $\mathbf{K}_{\mathbf{2}} \mathbf{O}$ & $\mathbf{N a}_{\mathbf{2}} \mathbf{O}$ & $\mathbf{S O}_{\mathbf{3}}$ & $\mathbf{P}_{\mathbf{2}} \mathbf{O}_{\mathbf{5}}$ & Loss \\
\hline WCP & 56.75 & 20.50 & 8.42 & 3.99 & 3.84 & 1.08 & 0.49 & 3.49 & 0.13 & 1.04 \\
Cement & 58.14 & 20.65 & 8.62 & 3.13 & 3.33 & 0.63 & 0.21 & 3.95 & 0.18 & 1.16 \\
\hline
\end{tabular}

It could be demonstrated that the chemical ingredients of WCP were similar to those of the cement P.O 42.5. Many calcium oxides existed because the used concrete was produced with calcium carbonate as aggregate. The particle size of WCP was mainly distributed in the range from 0.84 to $30 \mu \mathrm{m}$ (Figure 1), similar to the cement particle size. 


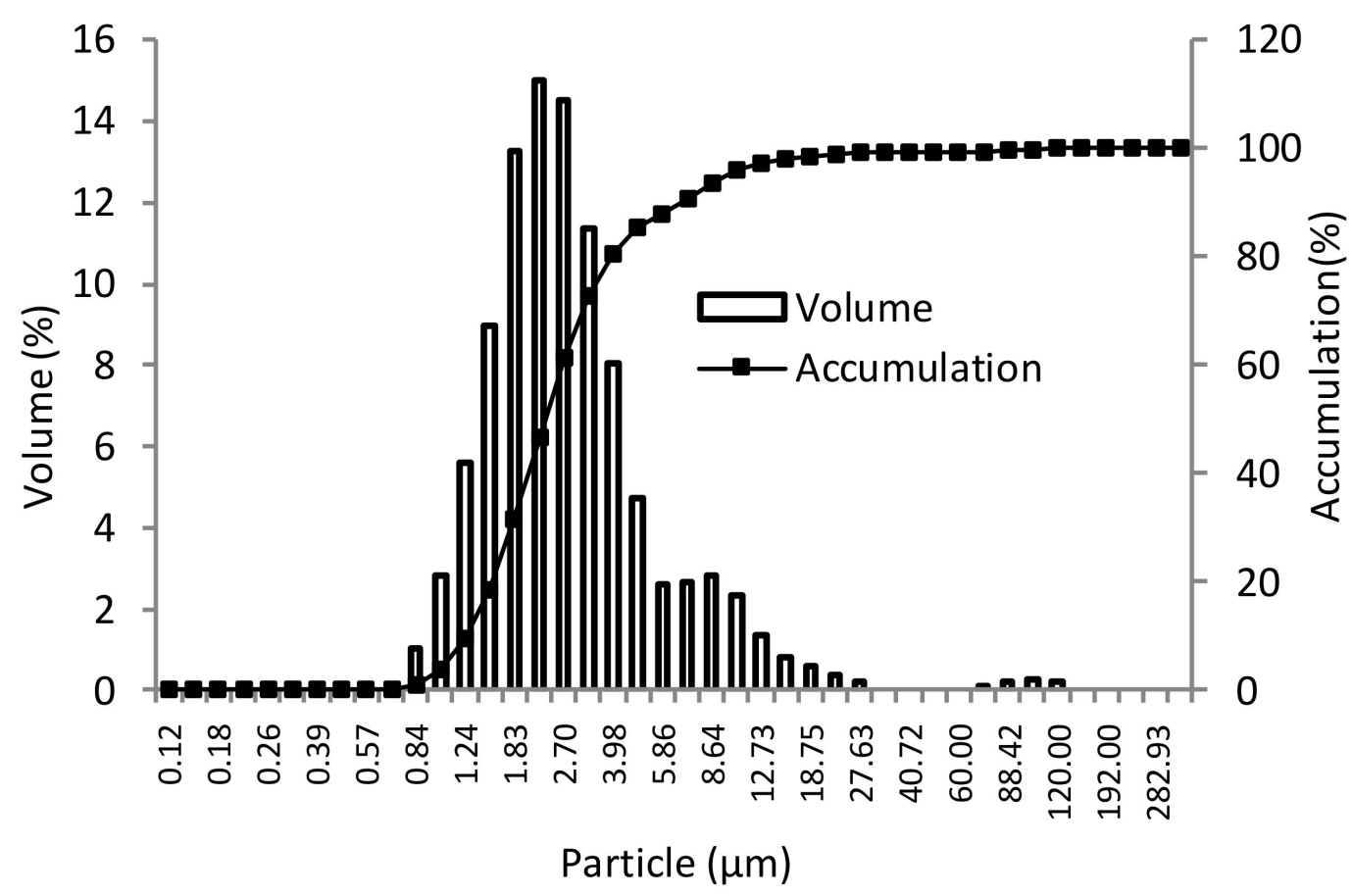

Figure 1. Waste concrete powder (WCP) particle distribution.

WCP was dealt with by thermal treatments of $200,400,600,700$, and $800{ }^{\circ} \mathrm{C}$ for $3 \mathrm{~h}$ in a labor heating furnace. Three $40 \times 40 \times 160 \mathrm{~mm}$ mortar cuboids for every sample were produced with the cement replaced by $30 \%$ thermally treated WCP according to the recipe in Table 2; then, its mechanical property and activity index were mainly measured according to the Chinese standard GB/T 17671 [23] and JG/T 486 [13]. In addition, heat flow change was measured by differential scanning calorimetry (DSC), and the mass loss, content of free calcium oxide, and particle size change of WCP by the thermal treatment were investigated. The crystalline structure and morphology of WCP were gauged by X-ray diffraction (XRD) and scanning electron microscopy (SEM), respectively, in order to further prove the effect of the thermal treatment for the property change of WCP.

Table 2. Recipe of the experiment according to Chinese Standard GB/T 17671.

\begin{tabular}{|c|c|c|c|c|c|c|c|c|c|c|}
\hline \multirow{4}{*}{ Samples } & Cement & \multicolumn{6}{|c|}{ WCP } & Standard Sand & Water & $\mathrm{W} / \mathrm{C}$ \\
\hline & \multirow{3}{*}{ g } & \multicolumn{6}{|c|}{$\mathrm{g}$} & \multirow{3}{*}{ g } & \multirow{3}{*}{ g } & \multirow{3}{*}{ / } \\
\hline & & \multicolumn{6}{|c|}{ Thermal Treatment $\left({ }^{\circ} \mathrm{C}\right)$} & & & \\
\hline & & 0 & 200 & 400 & 600 & 700 & 800 & & & \\
\hline E-0 & 450 & & & & & & & \multirow{7}{*}{1350} & \multirow{7}{*}{225} & \multirow{7}{*}{0.5} \\
\hline E-1 & \multirow{6}{*}{315} & 135 & & & & & & & & \\
\hline E-2 & & & 135 & & & & & & & \\
\hline E-3 & & & & 135 & & & & & & \\
\hline E-4 & & & & & 135 & & & & & \\
\hline E-5 & & & & & & 135 & & & & \\
\hline E-6 & & & & & & & 135 & & & \\
\hline
\end{tabular}

The mechanical properties were measured by the compression and folding experiment machine made by the SANS company. The content of free calcium oxide was measured by the FC- 6 digital free calcium oxide machine made in Shanghai, and, in this test, ethylene glycol was used to react with 
free calcium oxide, which resulted in the change in liquid conductivity. The free calcium oxide was measured because the machine could gauge the liquid conductivity. The laser particle size analysis machine made by Winner of Jinan gauged the sample size. Other testing devices, such as a mixer and grinding machine, were used in this study too.

Activity index (AI) is the ratio between the mechanical strengths of the concrete, whose $30 \%$ cements were replaced by a powder and those of the reference concrete according to the Chinese standard JG/T486 [13].

$$
\mathrm{AI}=\mathrm{F}_{\mathrm{a}} / \mathrm{F}_{\mathrm{b}} \times 100 \% .
$$

AI-activity index in $\% ; \mathrm{F}_{\mathrm{a}}-7$ and 28 day strength of concrete with $30 \%$ replacement of cement by an admixture in $\mathrm{MPa} ; \mathrm{F}_{\mathrm{b}}-7$ and 28 day strength of reference concrete in $\mathrm{MPa}$.

According to the requirement of Chinese GB/T 486, if the AI meets the values in Table 3, the powder can be regarded as an admixture used in concrete.

Table 3. Requirement of activity index (AI) values of compound mineral admixtures for concrete according to Chinese standard JG/T486-2015 [13].

\begin{tabular}{ccccc} 
& \multirow{2}{*}{ Day } & \multicolumn{3}{c}{ Activity of Compound Mineral Admixtures for Concrete } \\
\cline { 2 - 5 } & & Class I & Class II & Class III \\
\hline \multirow{2}{*}{ AI (\%) } & 7 & $\geq 80$ & $\geq 70$ & $\geq 65$ \\
\cline { 2 - 5 } & 28 & $\geq 90$ & $\geq 75$ & $\geq 70$ \\
\hline
\end{tabular}

\section{Results}

\subsection{Properties of WCP by Thermal Treatment}

DSC detection can explain the heat change of WCP in the process of thermal treatment (Figure 2), where a big endothermic peak occurred at temperatures from about 700 to $900{ }^{\circ} \mathrm{C}$ because of decomposition of calcium carbonate. WCP mass was lost in the thermal treatment process; with the increase in temperature, more mass losses occurred because of the water escape and chemical reaction. Figure 3 illustrates the mass change of WCP after the thermal treatment; with the increasing treatment temperature, the mass loss of WCP increased.

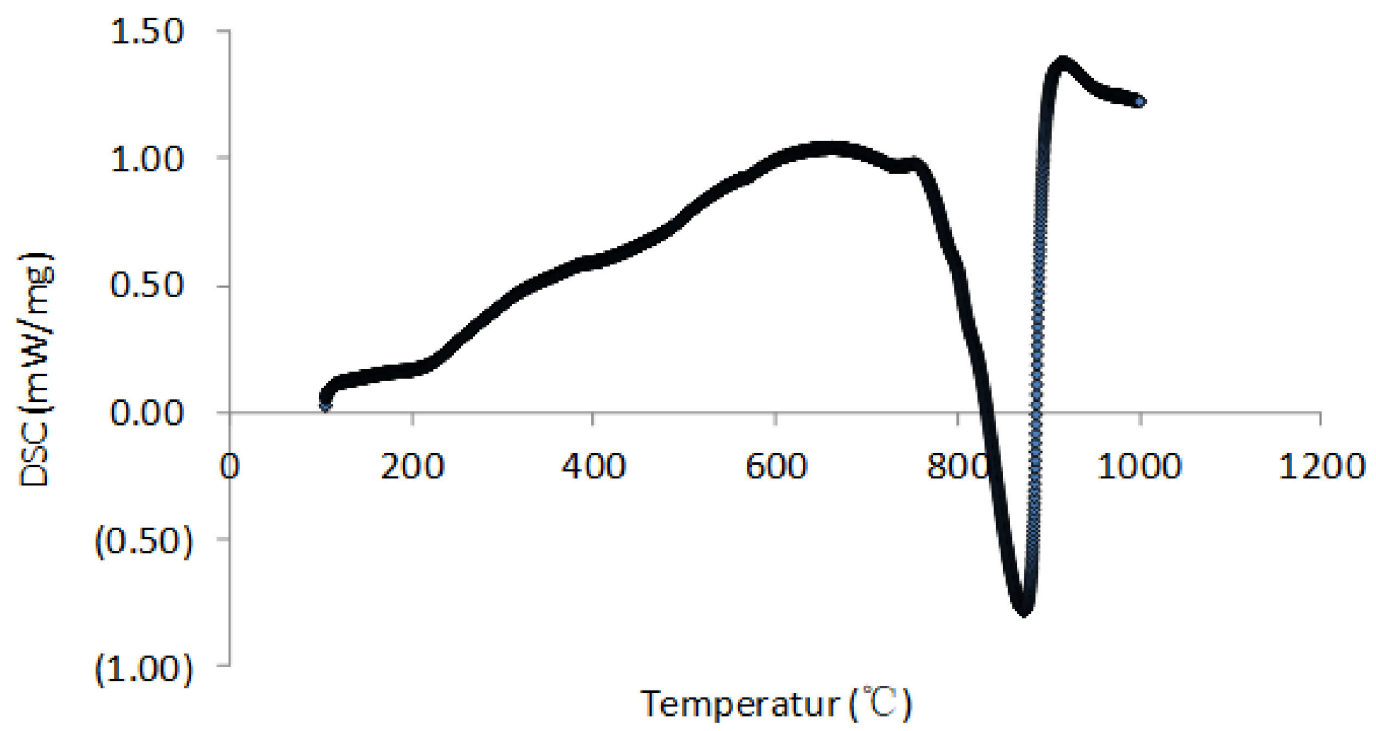

Figure 2. Heat flow change of WCP with differential scanning calorimetry (DSC) detection. 


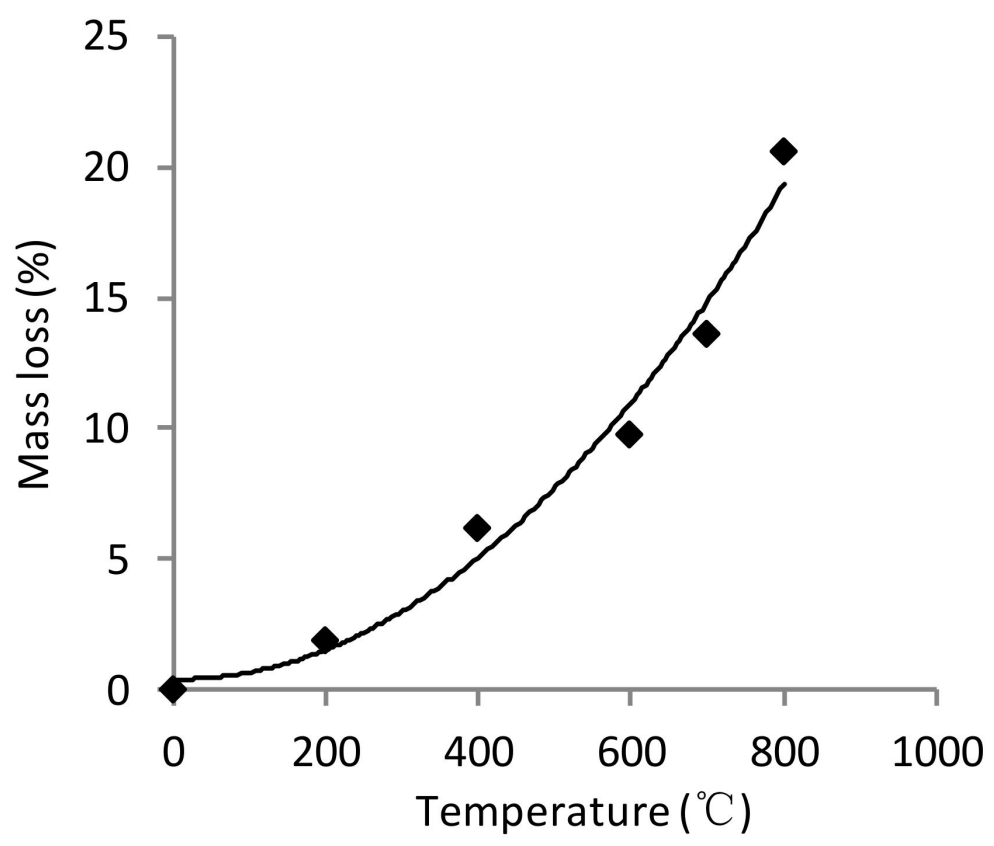

Figure 3. WCP mass losses with the thermal treatment.

In Figure 4, it is obvious that the free calcium oxide content increased with the increase in temperature; especially, at $800{ }^{\circ} \mathrm{C}$ treatment, the value was up to $3.6 \%$. Free calcium oxide could quickly react with water and more contents could affect the cement properties. The content of free calcium oxide in Portland linker was not more than 1.5\% according to Chinese standard GB/T 21372 [24].

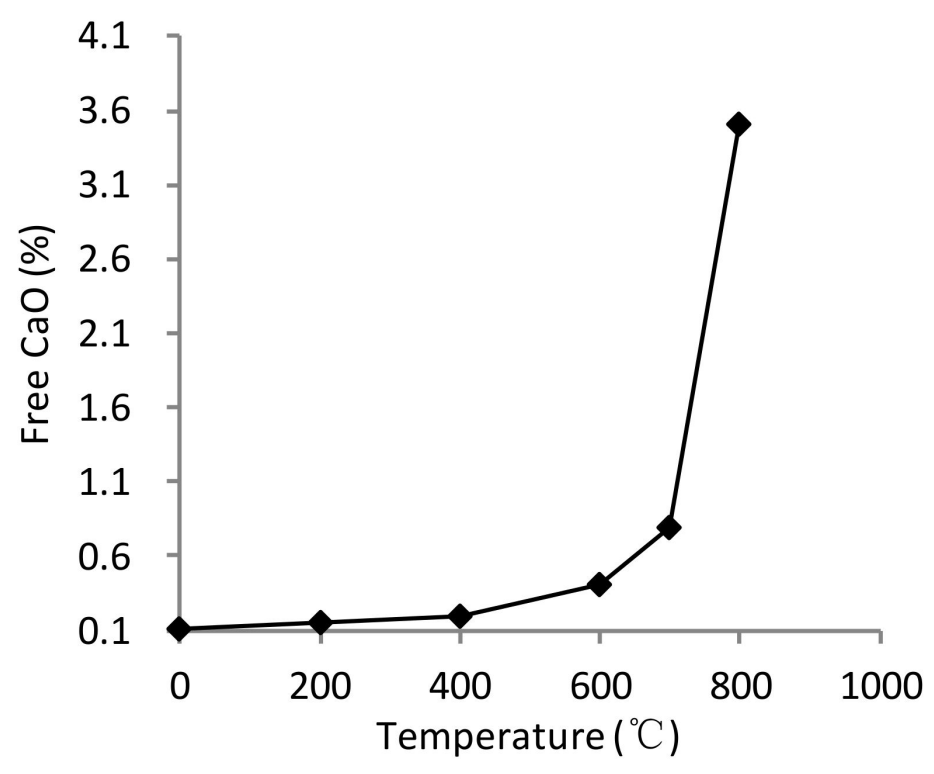

Figure 4. Free calcium oxide content in WCP.

In Figure 5, it was measured that the powder particle size was influenced by the temperature; it decreased with the thermal treatment of $700{ }^{\circ} \mathrm{C}$, while it increased for $600{ }^{\circ} \mathrm{C}$. With the thermal treatments of $700{ }^{\circ} \mathrm{C}$ and $600{ }^{\circ} \mathrm{C}$, the size of the $90 \%$ volume (D90) was 3.08 and $17.85 \mu \mathrm{m}$, respectively. This was affected by the structural transformation of $\mathrm{C}-\mathrm{S}-\mathrm{H}$, the specific surface area, and the pore volume of cement paste by $600{ }^{\circ} \mathrm{C}$ treatment, which was the biggest compared to those by heat treatment under $1000{ }^{\circ} \mathrm{C}$ [21]. 


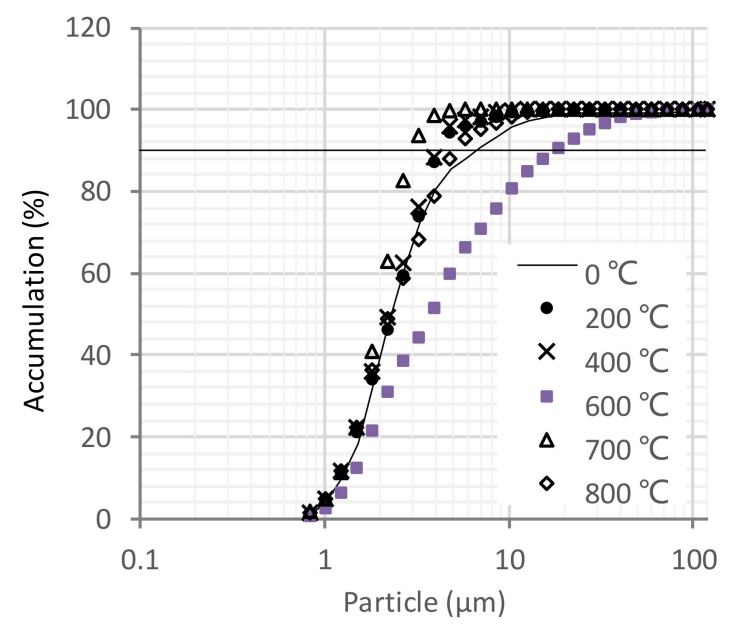

(a)

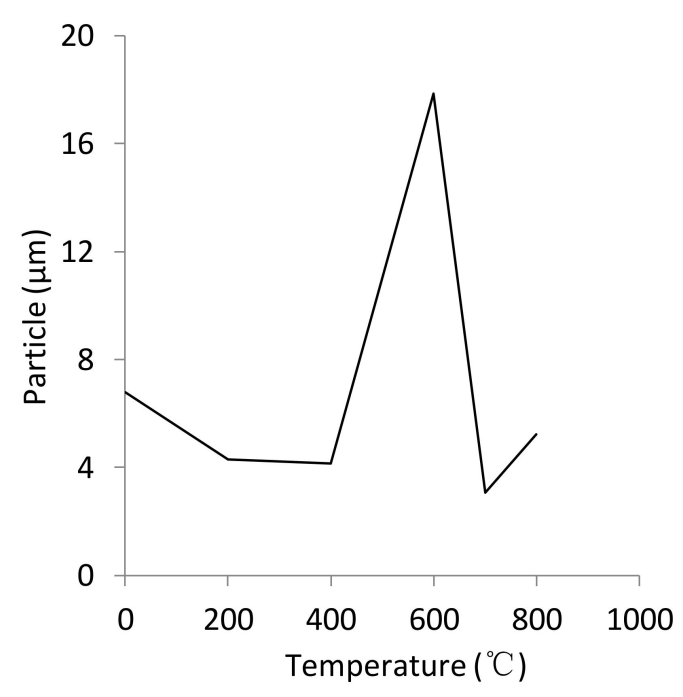

(b)

Figure 5. WCP particle analysis: (a) Accumulated particle size; (b) the particle size of 90\% volume (D90).

\subsection{Change of Activity Materials in WCP by the Thermal Treatment}

Although cement paste probably contained unhydrated clinker, it was not determined in samples of this study. WCP mainly comprises cement paste and concrete aggregate powder. Calcium carbonate is an inert material, and therefore, the WCP property is determined by the activity of cement paste. New active materials could be produced in WCP by the thermal treatment [25]. New larnite and calcium silicates $\left(\mathrm{Ca}_{3} \mathrm{SiO}_{5}\right.$ and $\left.\mathrm{Ca}_{2} \mathrm{SiO}_{4}\right)$ were measured in the $\mathrm{WCP}$ at $800{ }^{\circ} \mathrm{C}$ by XRD experiment, and they are active materials and can react with water (Figure 6).
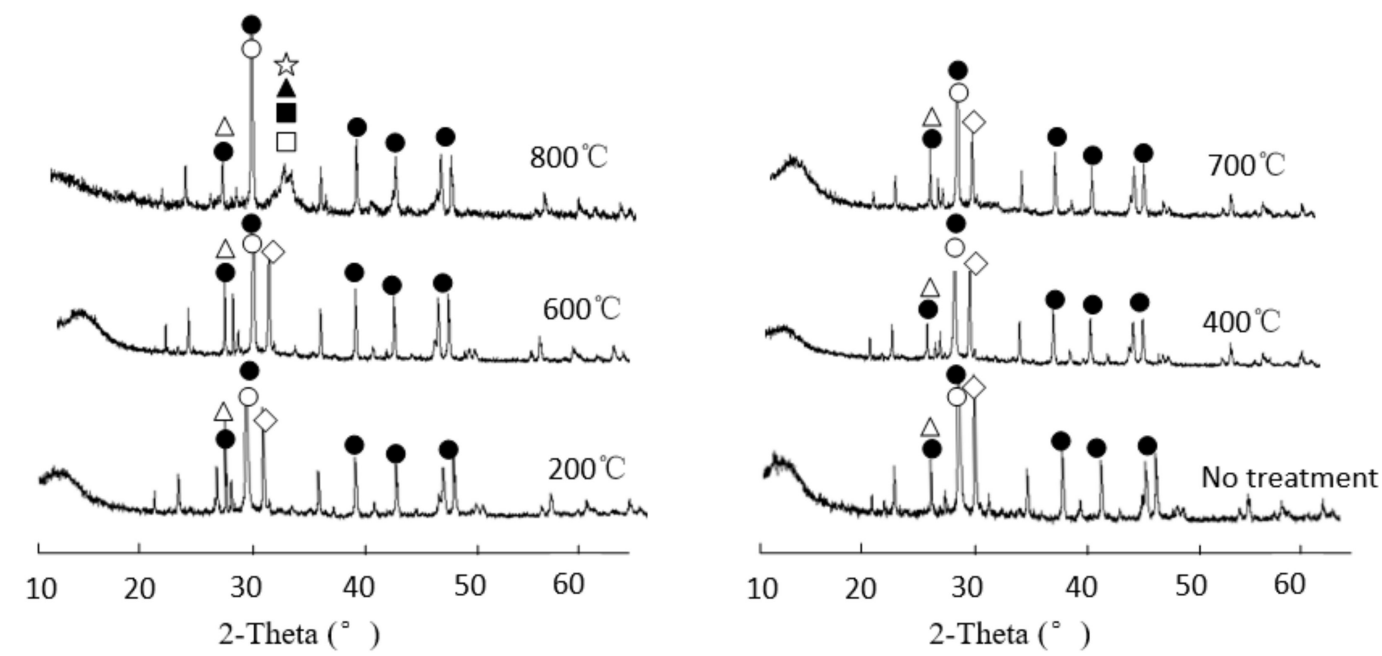

$$
\begin{aligned}
& \odot-\mathrm{CaCO}_{3} \bullet-\mathrm{CaO} \Delta-\mathrm{SiO}_{2} \diamond-\mathrm{CaMg}\left(\mathrm{CO}_{3}\right)_{2} \\
& \square-\mathrm{Ca}_{3} \mathrm{SiO}_{5} \mathbf{-}-\mathrm{Ca}_{2} \mathrm{SiO}_{4} \boldsymbol{\Delta}-\mathrm{Ca}_{3} \mathrm{Al}_{2} \mathrm{O}_{6} \underset{\sim}{- \text { Larnite }}
\end{aligned}
$$

Figure 6. Mineral compositions in WCP determined by XRD.

The SEM figures illustrated the particle characteristics of the WCPs without thermal treatment and with $600{ }^{\circ} \mathrm{C}, 700{ }^{\circ} \mathrm{C}$, and $800{ }^{\circ} \mathrm{C}$ treatments (Figure 7 ). 


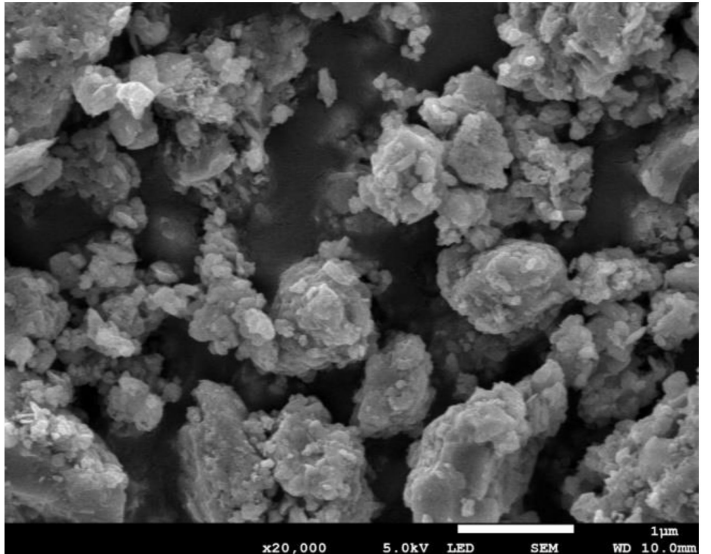

(a)

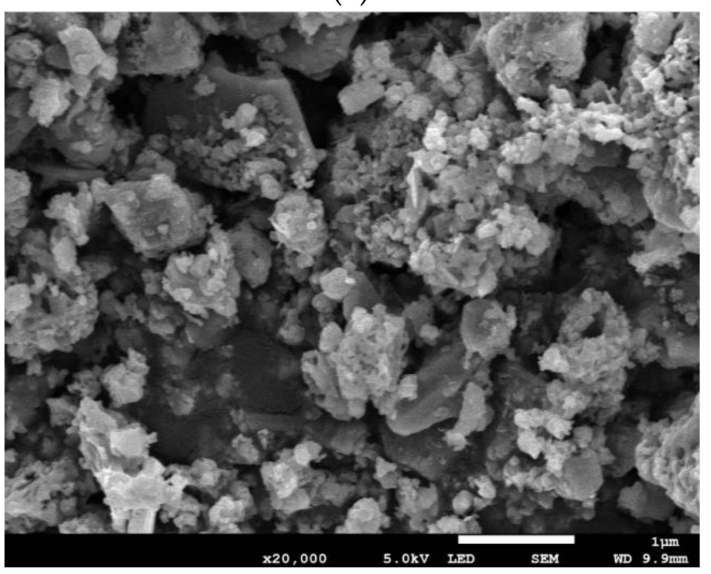

(c)

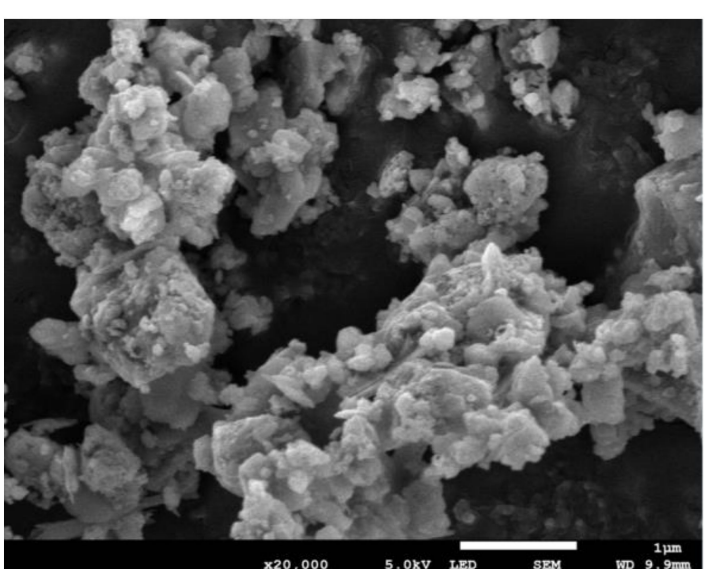

(b)

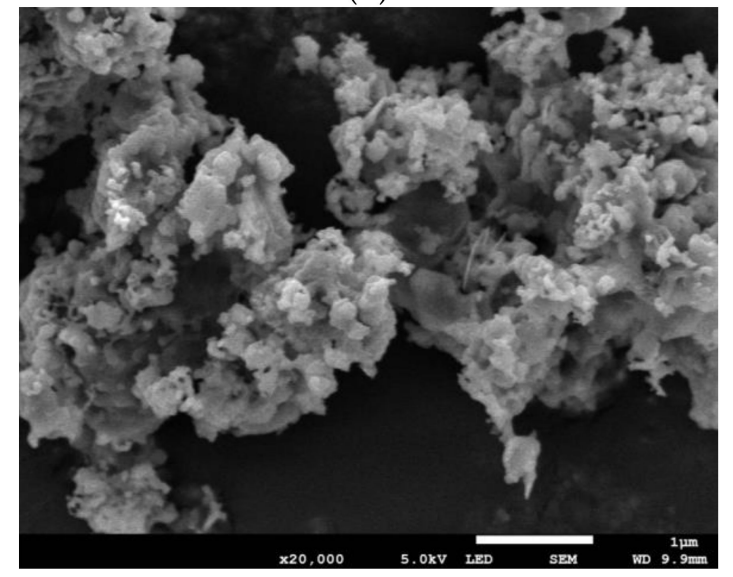

(d)

Figure 7. SEM detection for the microstructure with 20,000 times. (a) Original WCP, (b) WCP heated by $600{ }^{\circ} \mathrm{C}$, (c) WCP heated by $700{ }^{\circ} \mathrm{C}$, and (d) WCP heated by $800{ }^{\circ} \mathrm{C}$.

Compared to unheated WCP, big cluster structures like arborization in WCP were formed by $600{ }^{\circ} \mathrm{C}$ treatment. After $700^{\circ} \mathrm{C}$ treatment, small clusters could be observed, and the size of WCP heated by $800{ }^{\circ} \mathrm{C}$ was bigger than that of WCP heated by $700{ }^{\circ} \mathrm{C}$ but smaller than that of WCP heated by $600^{\circ} \mathrm{C}$. These results were consistent with the size change described in Figure 5 . Unlike those of the WCPs heated by $600{ }^{\circ} \mathrm{C}$ and without thermal treatment, the surfaces of WCPs heated by 700 and $800{ }^{\circ} \mathrm{C}$ had many holes, and those changes were probably caused by the dehydration and recrystallization of C-S-H [26] and the decomposition of calcium carbonate.

\subsection{Application of WCP in Mortar with the Replacement of Cement}

If WCP is used in concrete as an admixture, the mechanical strength of mortar must adhere to the regulations of the standard, which means that the activity index must overrun $65 \%$ of values of reference mortar according to the standard requirement in Table 3.

The mechanical strength of mortars is listed in Table 4. Using Equation 1, AI was calculated and is shown in Table 5. By reference to the Chinese standard (Table 3), AI values except those treated at $700{ }^{\circ} \mathrm{C}$ could not attain the requirement for the active mineral admixture used in concrete. The AI value of mortar with WCP heated by $700{ }^{\circ} \mathrm{C}$ could meet the class II requirement, which meant WCP heated by $700{ }^{\circ} \mathrm{C}$ could be regarded as an admixture for mortar or concrete. The mortar with WCP heated by $600{ }^{\circ} \mathrm{C}$ had the smallest $\mathrm{AI}$ value. The active larnite and $\mathrm{Ca}_{3} \mathrm{SiO}_{5}$ were gauged in WCP heated by $800{ }^{\circ} \mathrm{C}$ by XRD; however, the AI of mortar with WCP heated by $800{ }^{\circ} \mathrm{C}$ did not obviously exceed the value of $65 \%$. 
Table 4. Mechanical strengths of mortars with the heated WCP for replacing $30 \%$ cement.

\begin{tabular}{|c|c|c|c|c|c|c|c|c|}
\hline & \multirow{2}{*}{ Day } & \multirow{2}{*}{$\begin{array}{l}\text { Reference } \\
\text { Mortar }\end{array}$} & \multicolumn{6}{|c|}{ Replacement $30 \%$} \\
\hline & & & $0^{\circ} \mathrm{C}$ & $200{ }^{\circ} \mathrm{C}$ & $400{ }^{\circ} \mathrm{C}$ & $600{ }^{\circ} \mathrm{C}$ & $700{ }^{\circ} \mathrm{C}$ & $800^{\circ} \mathrm{C}$ \\
\hline \multirow{3}{*}{$\begin{array}{l}\text { Flexible strength } \\
\qquad(\mathrm{MPa})\end{array}$} & 3 & 5.44 & 3.58 & 3.33 & 3.66 & 3.81 & 4.91 & 3.96 \\
\hline & 7 & 7.27 & 4.43 & 5.72 & 6.52 & 5.15 & 6.42 & 5.36 \\
\hline & 28 & 8.79 & 4.63 & 6.18 & 7.06 & 5.89 & 6.83 & 6.23 \\
\hline \multirow{3}{*}{$\begin{array}{l}\text { Compressive } \\
\text { strength } \\
(\mathrm{MPa})\end{array}$} & 3 & 29.41 & 17.68 & 14.34 & 14.97 & 16.68 & 23.71 & 17.53 \\
\hline & 7 & 46.82 & 25.16 & 26.20 & 29.92 & 23.16 & 33.43 & 28.44 \\
\hline & 28 & 55.34 & 41.91 & 38.98 & 42.64 & 39.82 & 47.71 & 36.98 \\
\hline
\end{tabular}

Table 5. AI values for heated WCP according to the mechanical strengths.

\begin{tabular}{|c|c|c|c|c|c|c|c|c|}
\hline & \multirow{2}{*}{ Day } & \multirow{2}{*}{$\begin{array}{l}\text { Reference } \\
\text { Mortar }\end{array}$} & \multicolumn{6}{|c|}{ Replacement 30\% } \\
\hline & & & $0^{\circ} \mathrm{C}$ & $200^{\circ} \mathrm{C}$ & $400^{\circ} \mathrm{C}$ & $600{ }^{\circ} \mathrm{C}$ & $700^{\circ} \mathrm{C}$ & $800^{\circ} \mathrm{C}$ \\
\hline \multirow{3}{*}{$\begin{array}{l}\text { AI of flexible strength } \\
(\%)\end{array}$} & 3 & 100 & 65.8 & 61.2 & 67.3 & 70.0 & 90.0 & 72.8 \\
\hline & 7 & 100 & 60.9 & 78.7 & 89.7 & 70.8 & 88.3 & 73.7 \\
\hline & 28 & 100 & 52.7 & 70.3 & 80.3 & 67.0 & 77.7 & 70.9 \\
\hline \multirow{3}{*}{$\begin{array}{l}\text { AI of compressive strength } \\
(\%)\end{array}$} & 3 & 100 & 60.1 & 48.8 & 50.9 & 56.7 & 80.6 & 59.6 \\
\hline & 7 & 100 & 53.7 & 56.0 & 63.9 & 49.5 & 71.4 & 60.7 \\
\hline & 28 & 100 & 75.7 & 70.4 & 73.5 & 72.0 & 86.2 & 66.8 \\
\hline
\end{tabular}

\section{Discussion}

Property changes of WCP with thermal treatment and the use of WCP-replaced cement in concrete were studied in this study. Finer WCP particles at $700{ }^{\circ} \mathrm{C}$, as well as new active materials $\beta-C_{2} S$ and $\mathrm{Ca}_{3} \mathrm{SiO}_{5}$ in WCP heated by $800{ }^{\circ} \mathrm{C}$, were detected. Activity indexes (AIs) of WCPs by testing and calculating the mechanical strength were carried out. The finer WCPs with $700{ }^{\circ} \mathrm{C}$ thermal treatment achieved an optimum AI.

The mortar with thermally treated $\mathrm{WCP}$ by $700{ }^{\circ} \mathrm{C}$ treatment exhibited better mechanical performance because of its smaller particle size, which meant a better packing due to the filler effect, where it was proved by Berodier et al. that the presence of "inert" fillers could induce shearing in the mixing, which was recognized to affect hydration. Smaller particles could enhance the shearing, generate more nucleation sites on the cement surface, and increase the hydration acceleration rate [27].

WCP treated by $700{ }^{\circ} \mathrm{C}$ treatment can be reused as an admixture in concrete by the $30 \%$ replacement of cement, which can meaningfully realize up-cycling for concrete waste.

\section{Conclusions}

WCP was heated by $200^{\circ} \mathrm{C}, 400{ }^{\circ} \mathrm{C}, 600^{\circ} \mathrm{C}, 700^{\circ} \mathrm{C}$, and $800^{\circ} \mathrm{C}$ and added in mortar, replacing $30 \%$ cement. Some properties of WCP and the mechanical strength of Mortar were determined. The following conclusions were obtained.

(1) The particle size of waste concrete powder changed after heat treatments of $200{ }^{\circ} \mathrm{C}, 400^{\circ} \mathrm{C}, 600{ }^{\circ} \mathrm{C}$, $700{ }^{\circ} \mathrm{C}$, and $800{ }^{\circ} \mathrm{C}$; the treatment of $700{ }^{\circ} \mathrm{C}$ decreased the particle size of WCP; and its D90 size was reduced by $55 \%$ with comparison to the original WCP.

(2) More mass loss and free calcium oxide generation in WCP occurred after the heat treatment in $800{ }^{\circ} \mathrm{C}$; furthermore, some active materials in WCP treated at $800{ }^{\circ} \mathrm{C}$ were determined by XRD detection.

(3) The activity index (AI), which was measured by the ratio of mechanical strengths between the mortar with $30 \%$ replacement of cement by WCP to those of the original mortar, demonstrated that the $\mathrm{WCP}$ treated at $700{ }^{\circ} \mathrm{C}$ could be used in concrete as an admixture. 
Author Contributions: Conceptualization and writing-original draft preparation, Y.S.; data curation, C.O., S.L. and J.Z.; writing-review and editing, Q.T. All authors have read and agreed to the published version of the manuscript.

Funding: This research was funded by the Shandong province key R\&D program (Public Welfare) 2019, Grant number 2019GSF109108, the scientific research foundation for the returned overseas Chinese scholars, State Education Ministry, grant number: (2013)1792 and the fund project of collaborative Innovation Center of green building of Shandong Province.

Acknowledgments: The authors would like to thank S.S. Liu for his contribution of SEM images detection.

Conflicts of Interest: The authors declare no conflict of interest.

\section{References}

1. Linss, E. Untersuchungen zur Leistung Schallimpulszerkleinerung fuer die selective Aufbereitung von Beton. Master's Thesis, Bauhaus-Universität Weimar, Weimar, Germany, 2008.

2. Sáez del Bosque, I.F.; van den Heede, P.; de Belie, N.; Sánchez de Rojas, M.I.; Medina, C. Carbonation of concrete with construction and demolition waste based recycled aggregates and cement with recycled content. Constr. Build. Mater. 2020, 234, 117336. [CrossRef]

3. Bendimerad, A.Z.; Delsaute, B.; Rozière, E.; Staquet, S.; Loukili, A. Advanced techniques for the study of shrinkage-induced cracking of concrete with recycled aggregates at early age. Constr. Build. Mater. 2020, 233, 117340. [CrossRef]

4. Sui, Y.; Mueller, A. Development of thermo-mechanical treatment for recycling of used concrete. Mater. Struct. 2012, 45, 1487-1495. [CrossRef]

5. Lu, B.; Shi, C.; Zhang, J.; Wang, J. Effects of carbonated hardened cement paste powder on hydrationand microstructure of Portland cement. Constr. Build. Mater. 2018, 186, 699-708. [CrossRef]

6. Wang, J.; Zhang, J.; Cao, D.; Dang, H.; Ding, B. Comparison of recycled aggregate treatment methods on the performance for recycled concrete. Constr. Build. Mater. 2020, 234, 117366. [CrossRef]

7. Wang, J.; Mu, M.; Liu, Y. Recycled cement. Constr. Build. Mater. 2018, 190, 1124-1132. [CrossRef]

8. Xuan, D.X.; Shui, Z.H. Rehydration activity of hydrated cement paste exposed to high temperature. Fire Mater. 2011, 35, 481-490. [CrossRef]

9. Shui, Z.; Xuan, D.; Chen, W.; Yu, R.; Zhang, R. Cementitious characteristics of hydrated cement paste subjected to various dehydration temperatures. Constr. Build. Mater. 2009, 23, 531-537. [CrossRef]

10. Splittgerber, F; Mueller, A. Identification of the Type of Cement in Hardened Concrete and Mortars. In International Conference on Construction Hong Kong 2001; Conference Proceeding Volume One; Institution of Civil Engineers: London, UK, 2001; pp. 143-154.

11. Farzam, H.; Bolin, G.; Hove, R.H.; Marin, J.; Erlin, B.J.; Isabelle, H.L.; Mather., B.; Gibbe, F.K.; Kaetzel, H.L.; Meseguer, A.G.; et al. Cement and Concrete Terminology Reported by ACI Committee 116; American Concrete Institute: Farmington Hills, MI, USA, 2000.

12. Mateusz, P.; Lukasz, S. Selected physical properties of concrete modified using mineral powders. Procedia Eng. 2017, 172, 891-896.

13. JG/T 486. Compound Mineral Admixtures for Concrete; Ministry of Housing and Urban-Rural Construction of the People's Republic of China: Beijing, China, 2016. (In Chinese)

14. Aliabdo, A.A.; Elmoaty, M.A.; Aboshama, A.Y. Utilization of waste glass powder in the production of cement and concrete. Constr. Build. Mater. 2016, 124, 866-877. [CrossRef]

15. Donatello, S.; Cheeseman, M.; Tyrer, C.R. Comparison of test methods to assess pozzolanic activity. Cem. Conc. Comp. 2010, 32, 121-127. [CrossRef]

16. BS EN 196-5:2011. Methods of Testing Cement-Part 5: Pozzolanicity Test for Pozzolanic Cement; British Standards Institution: London, UK, 2011.

17. Kim, Y.J.; Choi, Y.W. Utilization of waste concrete powder as a substitution material for cement. Constr. Build. Mater. 2012, 30, 500-504. [CrossRef]

18. Bordy, A.; Younsi, A.; Aggoun, S.; Fiorio, B. Cement substitution by a recycled cement paste fine: Role of the residual anhydrous clinker. Constr. Build. Mater. 2017, 132, 1-8. [CrossRef]

19. Zhu, P.; Mao, X.; Qu, W.; Li, Z.; Ma, Z.J. Investigation of using recycled powder from waste of clay bricks and cement solids in reactive powder concrete. Constr. Build. Mater. 2016, 113, 246-254. [CrossRef] 
20. Schneider, U.; Herbst, H.-J. Permeabilitaet und Porositaet von Beton bei hohen Temperaturen. In Deutscher Ausschuss fuer Stahlbeton; Beuth Verlag GmbH: Berlin, Germany, 1989.

21. Schneider, U. Verhalten von Beton bei hohen Temperaturen. Deutscher Ausschuss fuer Stahlbeton; Verlag von Wilhelm \& Sohn: Berlin, Germany, 1982.

22. Wolf, G. Untersuchung Ueber das Temperaturverhalten eines Tunnelbetons mit spezieller Gesteinskoenung. Master's Thesis, Technische Universitaet Wien, Vienna, Austria, 2004.

23. GB/T17671. Method of Testing Cements-Determination of Strength; Chinese national bureau of quality supervision: Beijing, China, 1999.

24. GB/T 21372. Portland Cement Clinker; Chinese National Bureau of Quality Supervision: Beijing, China, 2008.

25. Dora, B. Hydraulisch Erhaertende Baustoffe Aus Betonbrechsand, Phasenaenderung Durch Temperaturebehandlung Und Einsatzmoeglichkeit. In Master's Thesis; TU Braunschweig: Braunschweig, Germany, 2001.

26. Zhang, Q.; Guang, Y.; Eduard, K. Investigation of the structure of heated Portland cement paste by using various techniques. Constr. Build. Mater. 2013, 38, 1040-1050. [CrossRef]

27. Berodier, E.; Scrivener, K. Understanding the Filler Effect on the Nucleation and Growth of C-S-H. J. Am. Ceram. Soc. 2014, 97, 3764-3773. [CrossRef]

(C) 2020 by the authors. Licensee MDPI, Basel, Switzerland. This article is an open access article distributed under the terms and conditions of the Creative Commons Attribution (CC BY) license (http://creativecommons.org/licenses/by/4.0/). 